\title{
Presence of Senecio sylvaticus L. (Asteraceae) in Turkey
}

\author{
Bilge Tunçkol ${ }^{1 *}$, HasanYaşayacak$^{2} \&$ Necmi Aksoy $^{3}$
}

${ }^{1}$ Bartın University Bartın Vocational School Department of Forestry and Forest Products Program, 74100 Bartın, Turkey ${ }^{2}$ Regional Forest Directorate of Zonguldak, Ereğli Forest District Directorate, 67300 Eregli-Zonguldak, Turkey ${ }^{3}$ Düzce University, Faculty of Forestry \& DUOF Herbaria Konuralp, 81620 Düzce, Turkey

* corresponding author (e-mail: bilgetunckol@gmail.com)

\begin{abstract}
The annual plant Senecio sylvaticus L. (Asteraceae) is regarded as a doubtfully recorded in Turkey. It has not been collected in the country since the first report of its occurrence in the north eastern Black Sea Region in 1875. This paper reconfirms the occurrence of Senecio sylvaticus in Turkey. New specimens were collected from the Ereğli and Alaplı regions (Zonguldak province, NW Turkey) in 2014. The species description, distribution maps and photographs are given.
\end{abstract}

Key words: Senecio sylvaticus L., Asteraceae, taxonomy, northern Turkey

\section{Introduction}

The genus Senecio is one of the biggest genera of family Asteraceae. This genus is represented by 102 species in the flora of USRR, 67 species in the flora of Europe, 29 species in the flora of Iran and 5 species in the flora of Palestine (Chater \& Walters 1976; FeinbrunDothan 1978; Shishkin 1995). Besides, it is represented by 48 taxa ( 39 species, 3 subspecies and 6 varieties) in the Flora of Turkey, whose revision was completed by Matthews (1975). In the $11^{\text {th }}$ volume of Flora of Turkey, 2 new species of the genus were added and the number of taxa increased to 50 (Kit Tan 2000). Then, two new species were discovered - one was growing around Lake Tuz (Salt Lake) and the other - between Ardahan and Şavşat. Thus, the total number of taxa increased to 52 (Vural et al. 2006; Budak et al. 2007). Finally, it was determined in $A$ Checklist of the Flora of Turkey (Vascular Plants) (Budak 2012) that the number of taxa is 31 .

Senecio sylvaticus was listed as a 'doubtfully recorded' at the end of the Senecio genus key in the Flora of Turkey (Matthews 1975; Davis et al. 1988; Güner et al. 2000). According to the records of the Flora of Turkey, the specimens of this species were collected by Boissier at A8 Trabzon-Of in 1875 (Boissier 1875), but it has not been re-found in this region since then. So, it was thought that Boissier's identification was probably wrong or the species was confused with Senecio viscosus.

\section{Material and methods}

During the floristic investigations, plant samples belonging to the Senecio genus were collected between Alaplı and Ereğli (in the borders of Karadeniz Ereğli Forest District) in the 2014 vegetation period. It was noted that these specimens have some different characteristics from Senecio lividus and S. vulgaris. They were checked according to the Flora of Turkey (Matthews 1975), but they were not determined. Then, the diagnostic key from the Flora Europaea (Chater et al. 1976) was used for the identification of collected specimens. Based on this key, it was determined that the collected samples belong to $S$. sylvaticus L.

\section{Results and discussion}

Senecio sylvaticus L. Sp. Pl. 868 (1753), (Figs. 1-2). Description: The collected samples of Senecio sylvaticus are $60-65 \mathrm{~cm}$ tall, each stem produces a cluster of 20 to 30 flowers heads, with sulcate stem and ascending branches, usually somewhat floccose, glandular-hairy, at least in inflorescence, but not viscid. 
Leaves irregularly pinnatifid; basal and lower cauline leaves oblanceolate in outline, shortly petiolate; middle and upper cauline leaves oblong in outline, auriculateamplexicaul. Capitula numerous, $4-5 \mathrm{~mm}$ in diameter, in a large terminal corymb. Involucral bracts $7-10 \mathrm{~mm}$, concolorous or slightly dark-tipped, glandular-hairy; supplementary bracts $3,1.5 \mathrm{~mm}$. Ligules $8-15$, very short and revolute immediately after anthesis, yellow. Achene with pappus 8-9 mm, achenes ca. 2-2.5 mm, rather sparsely subappressed-hairy at ribs. $2 n=40$.
Wood-margins and disturbed ground, especially on sandy soils. From Central Fennoscandia and North Central Russia southwards to Central Portugal, Central Italy and Bulgaria (cf. Chater \& Walters 1976).

Location/New localities: Examined specimens of Senecio samples were collected from the western part of the Black Sea Region A3: Zonguldak; Ereğli and Alaplı in the 2014 vegetation period. The samples from Ereğli were collected from Karakavuz location 1000 m a.s.l., on 22 August, and the samples from Alapli

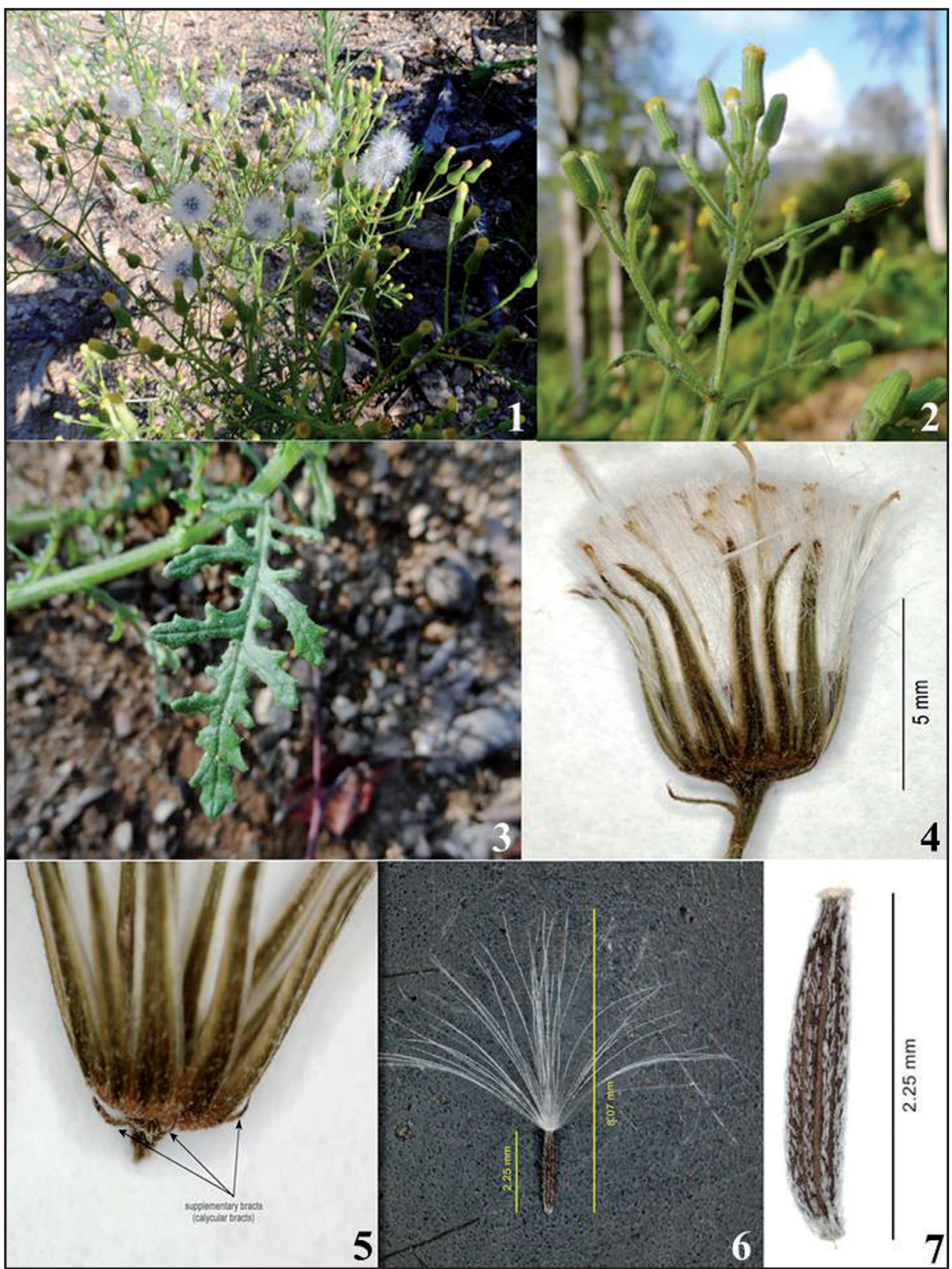

Fig. 1. General appearance of Senecio sylvaticus L.

Explanations: 1 - habitus, 2 - inflorescence (corymb), 3 - leaf, 4 - capitula, 5 - supplementary bracts, 6 - achene with pappus, 7 - achene (Bilge Tunçkol, Hasan Yaşayacak and Serdar Aslan) 


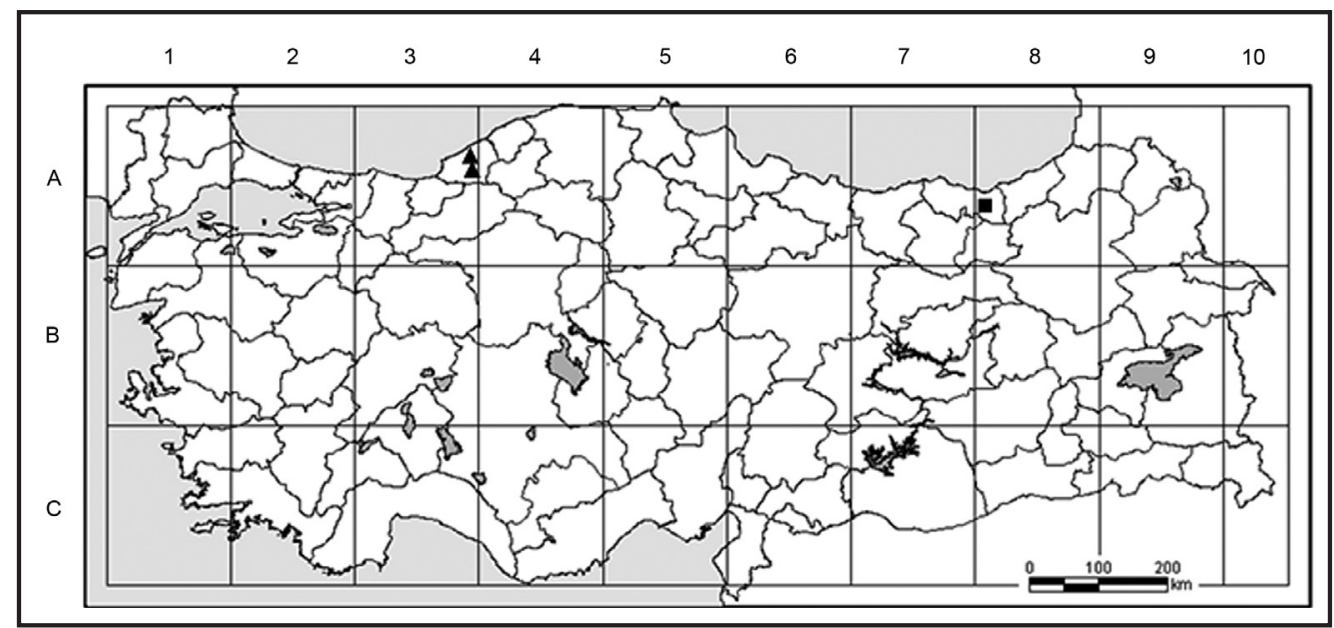

Fig. 2. Distribution map of Senecio sylvaticus in Turkey Explanations: $\boldsymbol{\Delta}$ - new localities, $\boldsymbol{\square}$ - doubtful locality (Boissier 1875)

were collected from Bendere location - 1200 m a.s.1., on 24 August 2014 (Herbarium of the Duzce University Faculty of Forestry, 5741).

As a result of the floristic investigations, the samples belonging to the Senecio genus were determined as $S$. sylvaticus. This identification proved the species presence in Turkey and, thus, the final number of taxa in the genus increased to 32 .

Key to the closely related Senecio species in the flora of Turkey

1. Capitula discoid 36. S. vulgaris

1. Capitula radiate

2. Achenes 3-5 mm, supplementary bracts $4-6 \ldots \ldots$. 39. S. lividus

2. Achenes less than $3 \mathrm{~mm}$, supplementary bracts $1-3$. 39a. S. sylvaticus
Habitat and e cology: The habitats of Senecio sylvaticus samples collected in 2014 are different in both regions (Alaplı and Ereğli). The samples from Ereğli were collected from the Fagus orientalis Lipsky forest, while the samples from Alapli were collected from unforested, stony areas and slopes occupied by such species like: Stellaria holostea L., Agrimonia eupatoria L., Daucus guttatus Sm. and Origanum vulgare subsp. vulgare $\mathrm{L}$.

Senecio sylvaticus is a new species in the Zonguldak province. Both newly discovered localities are under threat from forestry and animal grazing, therefore, it is suggested that this species should be ranked in the category "Vulnerable" (VU) in Turkey (IUCN 2001).

Acknowledgements. The authors are thankful to Assoc. Dr. Ümit Budak and Expert Serdar Aslan for their support in the identification of the samples.

\section{References}

Boissier E. 1875. Flora Orientalis, vol. 3, pp: 383-414.

Budak Ü., Hamzaoğlu E. \& Aksoy A. 2007. A New Record for the Flora of Turkey, Tephroseris cladobotrhys (Ledeb.) Griseb. \& Schenk (Senecioneae, Asteraceae). Turkish Journal of Botany 31: 265-268.

Budak Ü. 2012. Senecio. In: A. Güner, S. Aslan, T. Ekim, M. Vural \& T. BABAÇ (eds.). A Checklist of the Flora of Turkey (Vascular Plants), pp. 199-201. Nezahat Gökyiğit Botanik Bahçesi ve Flora Araştırmaları Derneği Yayını, İstanbul.

Chater A. O. \& Walters S. M. 1976. Senecio L. In: T. G. Tutin, V. H. Heywood, N. A. Burges, D. M. Moore, D. H. Valentine, S. M. Walters \& D. A. Webb (eds.). Flora Europaea, vol. 4, pp. 191-205. Cambridge University Press, Cambridge.
Davis P. H., Mill R. R. \& TAN K. 1988. Flora of Turkey and the East Aegean Islands, vol. 10, pp. 463. Edinburgh University Press, Edinburgh.

Feinbrun-Dothan N. 1978. Senecio L. In: N. Feinbrun-DoTHAN (ed.). Flora Palaestina, vol. 3, pp. 354-357. The Israel Academy Sciences and Humanities, Jerusalem.

Güner A. \& Özhatay N. \& Ekim T. \& Başer K. H. C. 2000. Flora of Turkey and the East Aegean Islands, vol. 11, pp. 150-170. Edinburgh University Press, Edinburgh.

IUCN 2001. IUCN Red List Categories and Criteria. Version 3.1. IUCN Species Survival Commission. IUCN, Gland, Switzerlandand Cambridge, UK.

TAN Kit. 2000. Senecio L. In: A. GÜNER, N. ÖZhatay, T. EkIM \& K. H. C. BAŞER (eds.). Flora of Turkey and the East 
Aegean Islands, vol. 11, pp: 156-157. Edinburgh University Press, Edinburgh.

Matthews V.A. 1975. Senecio L. In: P. H. Davis (ed.). Flora of Turkey and the East Aegean Islands, vol. 5, pp. 80-97. Edinburgh University Press, Edinburgh.

SHISHKIN B. K. 1995. Senecio L. In: B. K. SHISHKIN \& E. G. Bobrov (eds.). Flora of the U.S.S.R., vol. 26, pp.
801-908. Bishen Singh Mahendra Pal Singh \& Koeltz Scientific Books, Dehra Dun.

Vural M. \& Aytaç Z. \& AdigüZel N. 2006. Saponaria karapinarensis, Senecio salsuginea and Centaurea tuzgoluensis, Three New Species from Central Anatolia Turkey, Belgian Journal of Botany 139(2): 252-260. 